\title{
The Exploration of College English Teaching Mode in Net Environment with Modern Information
}

\author{
Nan Shi ${ }^{1}$ Yang Zhang ${ }^{2}$ \\ ${ }^{1}$ Xingtai University, Xingtai, Hebei, China, xsshinan@yahoo.com.cn \\ ${ }^{2}$ Xingtai University, Xingtai, Hebei, China, zhen_zhi@126.com
}

\begin{abstract}
With the enrollment expansion of college increasing, the traditional multimedia teaching method is very difficult to adapt to the requirement under the net environment with modern information. Thus, the author made sufficient research on the existed teaching model and found its inherited advantages under the new modern net environment. Based on this, the author thought too much about the function of intellectual terminal, such as cell phone, and came up with a new teaching model on the basis of wireless campus net to make up for the lack of traditional teaching materials, for example, Internetclassroom, self-study center and language laboratory. The exploration of the new model must make brand-new development for English teaching.
\end{abstract}

Keywords: Wireless Campus Net, Intellectual Terminal, Teaching Model.

\section{Introduction}

The traditional multimedia technology is made up of multimedia classroom, language laboratory, internet-classroom and self-study center, which are all computercentered and seen as systematic software served by LAN (local net area) for teaching and learning of college English. It adopts the technology of windows media, network English courseware as its core, with the support of teaching management system, and makes rational use of English resources efficiently for the service of full implementation of informationizing modern English teaching. However, with the enrollment expansion, it is lack of educational resources and unable to make students learn English everywhere and every time. The new teaching model should be based on modern information technology, especially network technique, which makes teaching English develop along individualism and initiative beyond the limitation of time and place. So with the massive use of intellectual terminals, such as cell phones, as well as on the basis of campus wireless network, the essay presented a new teaching model based on campus wireless network.

\section{Advantages of Traditional Multi- media Teaching Model}

\subsection{Improving Interesting in The Class}

As we all know, interest is the best teacher. But in the process of English teaching, English class often consists purely of words, grammars, the usages of phrase and analysis of complex sentences, which aim at only teaching knowledge points boringly. The cramming not only made students dull and uninterested, but the teacher himself felt insipid. The addition of multimedia will improve this situation 
greatly. For example, in College English, relativity appeared in one text named The Public Attitude Towards Science. It is difficult for the students of arts to understand the uninteresting theory. We can first use sci-fi movie clips, such as "Star Trek", to introduce the concepts of spacetime continuum, wormholes and time dilation based on relative theory and arouse students' interest; then explain what relativity is in the way of joking, for instance, if you have been at the stove with the closest person for an hour, you will feel just like five minutes, in turn, if you yourself have been for five minutes, maybe you will feel just like an hour. This is relativity. In such relaxed environment, students naturally have interest in the boring text and improve their listening ability with the help of English movie clips.

\subsection{Improving Students' Quality of Information}

Teachers only explain the teaching materials in traditional teaching process, while students are purely knowledge receivers, who simply need to listen carefully and totally accept everything the teacher explained. But in this multimedia teaching mode, its amount of information is far more than the simple introduction of background knowledge, so students need ability to obtain information, which is necessary for the students in the age of network and information. It is important to cultivate students' ability to obtain, use, process and exchange the information. They should learn how to choose and filter the information with classification. In this way we can greatly improve the information literacy of students in the era of information explosion.

\subsection{Strong Subjectivity}

In the process of multimedia network, students can carry out listening, grammar, reading and writing training according to the teaching requirements. Although the process certainly is in the state from delivering to accepting, it also includes students' thinking and exploring, in which they can make sure what their question is and find its solution. In the process of their solution, they not only practice their ability to collect and identify the information, but also put forward hypotheses to prove, as well as cooperate with their companions, therefore they have strong subjectivity.

\subsection{Relaxation}

According to second law of language learning, the learner tends to lose practicing chance because many learners dare not to open mouth in the front of their classmates in the class. Due to the same reason, many students who want to practice oral English are shame to take part in the scene like English corner. But in the multimedia classroom with network, they are not nervous and relaxed to exercise. On the network, they are enthusiastic to discuss in groups without worrying about humiliation of their mistakes. As a result, the stronger their participation consciousness gets, the higher their enthusiasm to study is.

\section{The Improved Plan for Multimedia Teaching Model of College English in the New Environment}

There is no doubt that the application of multimedia in English class has provided the substantial foundation for the transformation of the traditional teaching model. In the past, we have established many teaching mode such as the teacher centered teaching model and the studentcentered model. The teacher centered teaching model can also be called the traditional computer-assisted teaching mode as is shown in figure 1. And the student 
centered model is a kind of exploratory teaching model, which offers a strong self reflection; the relation of the four elements can be presented in figure 2 .

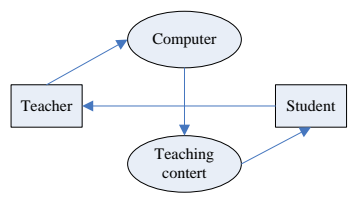

Fig. 1: Teacher centered teaching model.

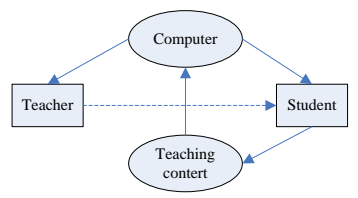

Fig. 2: Student centered model.

The above two represent the model of multimedia in English class, but the students can't use it casually. With the enrollment expansion, these teaching resources are insufficient, what's more, the above two models greatly limit the development of multimedia in English class in the modern network environment. So for the strong construction of campus network and widely use of intellectual terminals such as intelligent cell phone, this paper presents an improved teaching model based on campus network, as is shown in figure 3 .

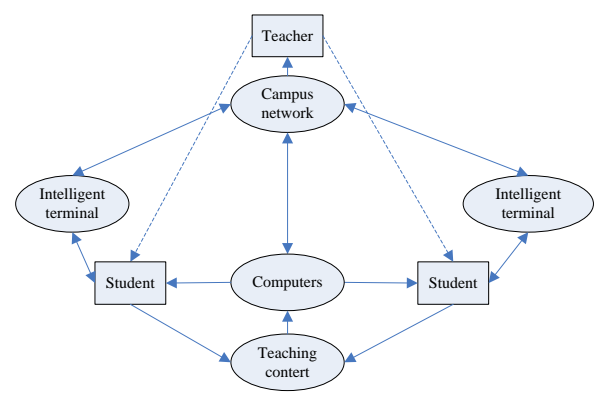

Fig. 3: Campus network and intelligent terminal model.
This model has changed the simplification of multimedia teaching, especially the introduction of intelligent terminal, mobile phone, makes the students learn all the time. Now the programming of intelligent phone such as the Android and Apple system grows vigorously, which will promote the development of multimedia teaching model much more under the modern information network environment. Almost all the students have a mobile phone and also use the instant messaging software, like QQ and micro message etc. With their increasing reliance on mobile phone, this teaching model can lead students' love of the phone to learn English correctly. We can take advantage of campus network and instant messaging software to build various online virtual English corners more convenient and more intelligent. The application of the instant messaging technology, virtual network group chat and private chat, has natural advantage to English corner. The network makes the students no longer shy or nervous and naturally makes up for deficiency of the traditional English corner which is often limited by weather conditions. This teaching model also increases the communication among students to ask students to learn English whenever and wherever possible, avoiding insufficiency of multimedia classroom which cannot be used at any time.

\section{Thinking and Suggestion}

- Strengthening to Develop The Technology of Campus Network

All the network teaching models are based on voice and video English corner of intellectual terminals, inseparable from the development of campus network. The integration of all teaching resources is also inseparable from the support of campus network technology.

- Actively Carrying out The Research on Information Technology and Inte- 
gration between Teaching and Learning English

We orientate first the resources of teaching and learning English. The information technology integrates innovation of English teaching model, utilization and construction of learning resource and the relationship between teachers and students smoothly into its service.

- Strengthening The Research on The Model of Teaching and Learning of Foreign Language in The Network Environment

There are many questions for the current teaching model of College English in the network environment. As a new teaching pattern, the related research lag of teaching model and strategy is the important reason to arouse controversy. We should strengthen theoretical and empirical study on cooperative learning and cooperative teaching, collaborative learning and collaborative teaching, blended learning, research of learning, exploration of learning, task of learning as well as online learning and offline learning in the network environment.

\section{Conclusion}

The multimedia network is just assistedequipment for education. Although it is more intelligent than teachers, it cannot take the place of the unique educational function of teachers. The reform of teaching model is not to make use of original teaching model to replace some traditional ones, but should be based on modern educational theory as guidance, serve as a link between past and future and bring forth the new through the old.

The reform should make our College English teaching contribute more to cultivate high-quality talents to meet our social and economic development requirements.

\section{References}

[1] Kearsley, G. Online Education: Learning and Teaching in Cyberspace. USA: Wadsworth/Thomason Learning, 2000.

[2] Jian Lin Chen. On the analysis of the center on computer and Classroombased Multimedia College English teaching model of student center. Foreign language teaching, 2005.

[3] Gardner, D. and L. Miller. Tasks for Independent Language Learning. Alexandria, VA: TESOL. Shanghai: Shanghai Foreign Language Education Press, 1996.

[4] Jian Lin Chen. From counseling to guide foreign language teaching: a new trend in the development of the computer, 2005.

[5] Li Ping Jiang. Based on the English subject learning website for university English autonomous learning mode. Foreign language and foreign language teaching, 2006. 